\title{
Religious Therapy as an Alternative Treatment in Reducing the Cortisol Hormone and Blood Sugar
}

\author{
Supriyadi $^{1}$, Ramelan Sugijana ${ }^{2}$, Shobirun ${ }^{3}$, Sudiarto ${ }^{4}$, Sri Utami Dwiningsih ${ }^{5}$ \\ 1, 2,3, 4,5 Department of Nursing, Politeknik Kesehatan Kemenkes Semarang, Indonesia \\ *Corresponding Author: Supriyadi, Politeknik Kesehatan, Kemenkes Semarang, Jl. Tirto Agung \\ Pedalangan, Banyumanik, Indonesia, Email: priex76@yahoo.com
}

\begin{abstract}
Background: Various studies have been done to see the effectiveness of action in dealing with stress in the elderly with hypertension, including dhikr jaher. This dhikr therapy focuses on certain words or sentences of the prayer repeatedly with regular rhythms accompanied by a submissive attitude to God according to the patient's belief.
\end{abstract}

The Objective: This research aims at identifying the effect of dhikr jaher (dhikr reads in a louder voice) in lowering the Hypothalamic-pituitary-adrenal Axis (HPA axis) regulation to reduce the production of stress hormones i.e. cortisol.

Method: This type of research is a Quasi-Experiment with Pretest-Posttest and Control Group Design.The sampling technique is continuous sampling with 40 respondents who meet the criteria set up. Respondents are divided into two groups namely the treatment group with dhikr jaher and the control group, each 20 respondents. The data is analyzed with Mann-Whitney test.

Result: Dhikr jaher has an effect on stress level and blood sugar level to older adults suffering from hypertension. Stress will affect the cortisol hormones that resist the effects of insulin and affect blood sugar and pressure levels.

Conclusion: Dhikr jaher is effective in reducing stress, hormone cortisol and blood sugar levels in elderly with hypertension.

Keywords: Dhikr Jaher, Cortisol Hormone, and Blood Sugar

\section{INTRODUCTION}

According to Wolf (2006), hypertension can be caused by several factors such as lifestyle (smoking, drinking alcohol), stress/anxiety, obesity, lack of exercise and heredity. Hyper tension causes the risk of stroke, heart disease, and kidney failure. At the end of the 20th century, heart illness and blood vessels, including those caused by hypertension, became the leading cause of death in developed and developing countries (Depkes, 2007).

The average cases of hypertension in Central Java were 9,800.54 cases, and the highest cases of hypertension in Central Java were in Kota Semarang with 67,101 cases (19.56\%) compared with the total number of hypertension in other cities/districts (Depkes, 2007). The incidence of hypertension in the last three years in Central Java increased by $427.22(52.4 \%)$ in
2014, 337.22 (52.91\%) in 2014 and 148,254 (53.06\%) in 2015 (Dinkes Propinsi Jawa Tengah, 2015). According to Pinson (2009), the prevalence of hypertension increases with age. Hypertension attacks middle-aged at age $55-64$ years. After the age of 69 years (elderly) the prevalence of hypertension increases to $50 \%$.

Methods of stress control and anxiety psychotherapy are very important because they are safe for the elderly due to no effects of allergic or drug effects. Psychotherapy methods depend on the needs of both individuals and families. Spiritual therapy emotional method of dhikr is one of the psycho religious treatments. This therapy uses the development techniques of the relaxation system with a mental approach. This dhikr therapy focuses on certain words or sentences of prayer repeatedly with regular rhythms accompanied by a submissive attitude to God according to the patient's belief. At the 
time of dhikr, the reciters will feel relaxed that there is an increase in the process of traveling neurotransmitter signals that decrease the regulation of hypothalamic-pituitary-adrenal Axis (HPA axis) thereby reducing the production of stress hormones namely cortisol (Church, 2009). Therefore, researchers are interested in analyzing the dhikr as a stress coping methods among elderly people with hypertension .

\section{Materials And Methods}

This research type is a quasi-experiment with pretest-posttest and control group design. The sample in this study were 40 respondents divided into two groups namely the intervention group with dhikr jaher and the control group each 20 respondents. The sampling technique is consecutive sampling. The data collection tool is a questionnaire to measure the stress level, stethoscope and blood pressure meter to measure blood pressure and standard operating procedure for treatment with dhikr. Measure ment of cortisol content is through enzymelinked immunosorbent assay (ELISA) exami nation, and blood glucose level is measured with a glucometer.

Characteristic of respondent observed include age, education, job, cortisol level and blood sugar level before and after giving the Dhikr Jaher. The bivariate analysis used in this study is the Wilcoxon test to find out the difference between treatment group and control group.

\section{RESULTS AND DISCUSSIONS}

\subsection{Result}

Characteristics of respondents indicated that most of the interviewees were female (17.0\%) in both treatment and control groups. The features of education based on the number of respondents were 11 elementary school students $(55 \%)$ in the treatment group and $10(50 \%)$ in the control group. Occupational characteristics, most of the respondents did not work as many as $11(55 \%)$ in the treatment group and as many as $12(60 \%)$ in the control group. Characteristicbased on age indicated that the average of respondent was 64.6 years old, with standard deviation 2.93, age minimum 60 years and maximum 70 years in treatment group while respondent in control group was average 64.7 years with standard deviation 3. 29, age minimum 60 years maximum of 70 years. Stress scores before being given the treatment of Dhikr Jaher obtained a mean value of 20.50 , and standard deviation 2.37. The stress score after given Dhikr Jaher got the mean value of 16.90, and standard deviation 1.29.

Wilcoxon statistical test results obtained p-value 0.000 denoting $\mathrm{Ho}$ is rejected, and $\mathrm{Ha}$ is accepted meaning there is a significant difference in stress score before and after given Dhikr Jaher. The stress score on the first observation found the mean value of 19.55 , and the standard deviation of 2.16 while the stress score on the second observation obtained the mean value of 19.80 , and standard deviation 2.88 .

Wilcoxon statistical test results obtained p-value 0.560 denoting $\mathrm{Ho}$ is accepted and $\mathrm{Ha}$ is rejected meaning there is no difference in stress scores on the first and second observations.

Levels of cortisol hormone before dhikr were given indicated a mean value of 97.61, and a standard deviation of 3.29 , while the levels of cortisol hormone in the after given Dhikr Jaher obtained mean value 63.68, and standard deviation 2.74 .

T-test statistic test results obtained p-value 0 . 000 indicating $\mathrm{Ho}$ is rejected and $\mathrm{Ha}$ is accepted, meaning there is a significant difference in cortisol hormone levels before and after given Dhikr Jaher.

Levels of cortisol hormone in the first observation obtained a mean of 65.12, and standard deviation 3.67, while the levels of the hormone cortisol on the second view obtained the mean value 71.03 , and standard deviation 4.59.

Wilcoxon statistical test results obtained p-value 0.351 indicating that $\mathrm{Ho}$ is rejected and $\mathrm{Ha}$ is accepted, meaning there is no difference in cortisol hormone levels on first and second observations.

Blood sugar levels before the dhikr being administered achieved a mean of 105.55, and a standard deviation of 14.54. The blood sugar level after given dhikr jaher obtained the mean value of 101.25, and the standard deviation of 11.04 .

Wilcoxon statistical test results obtained p-value 0.003 then $\mathrm{Ho}$ is rejected and $\mathrm{Ha}$ is accepted, meaning there is a significant difference in blood sugar levels before and after given Dhikr Jaher.

Blood glucose level at first observation was obtained mean value 101, 25 and standard 
deviation 11, 04. The blood sugar level on second observation got the mean value 113.90, and standard deviation 23.18.

Wilcoxon statistical test results obtained p-value 0.470 then $\mathrm{Ho}$ is accepted and $\mathrm{Ha}$ is rejected, saying there is no significant difference in blood glucose levels on first and second observations in the control group.

Table1. Differences in Stress Score on Intervention Group and Control Group in Elderly with Hypertension

\begin{tabular}{|l|c|c|c|l|}
\hline Groups & $\begin{array}{c}\text { Score of } \\
\text { Stress } \\
(\text { Pre })\end{array}$ & $\begin{array}{c}\text { Score of } \\
\text { Stress } \\
\text { (Post) }\end{array}$ & $\boldsymbol{p}$ - value & $\begin{array}{l}\text { Differ } \\
\text { ences }\end{array}$ \\
\hline & $\begin{array}{c}\text { Mean } \pm \\
\text { SD }\end{array}$ & Mean \pm SD & & $\begin{array}{l}\text { Mean } \\
\pm \text { SD }\end{array}$ \\
\hline Interven & $20.50 \pm$ & $16.90 \pm$ & $\mathbf{0 . 0 0 0}$ & $3.60 \pm$ \\
tion & 2.37 & 1.29 & & 1.96 \\
\hline Control & $19.55 \pm$ & $19.80 \pm$ & $\mathbf{0 . 5 6 0}$ & $0.25 \pm$ \\
& 2.16 & 2.88 & & 1.55 \\
\hline $\boldsymbol{p}$ - value & $\mathbf{0 . 1 9 4}$ & $\mathbf{0 . 0 0 1}$ & & $\mathbf{0 . 0 0 0}$ \\
\hline
\end{tabular}

Table 1 shows that the results of different group test in pairs between groups before and after Dhikr Jaher obtained p-value $=0.000(p<0.05)$ meaning there is a significant difference in stress score before and after Dhikr Jaher. The result of different test of paired group between first and second observation in control group indicated $p=0.560(>0,05)$ meaning there is no difference of stress score between first and second observation. While the result of the different test in the unpaired group between group before treatment of Dzikir Jaher and control group indicated $\mathrm{p}$-value $=0.194(>$ 0.05 ), meaning there is no significant difference of stress score before Dhikr Jaher during first observation in control group. The different test results in the unpaired group between group after treatment of Dhikr Jaher and control group obtained $\mathrm{p}$-value $=0.001(\mathrm{p}<0.05)$, meaning that there is a significant difference of stress score after Dhikr Jaher and second observation in control group. And the result of difference test of the unpaired panel in the treatment group of Dhikr Jaher and control group displayed $\mathrm{p}$ value $=0.000(<0.05)$, meaning that there is a significant difference of stress score between the treatment group of Dzikir Jaher and control group.
Table2. Differences in Cortisol Hormone Levels in the Intervention and Control Group in the elderly with Hypertension

\begin{tabular}{|c|c|c|c|c|}
\hline Groups & $\begin{array}{c}\text { Cortisol } \\
\text { Level } \\
\text { (Pre) }\end{array}$ & $\begin{array}{c}\text { Cortisol } \\
\text { Level } \\
\text { (Post) }\end{array}$ & $p$ - value & $\begin{array}{l}\text { Differ } \\
\text { ences }\end{array}$ \\
\hline & $\begin{array}{c}\text { Mean } \pm \\
\text { SD }\end{array}$ & Mean \pm SD & & $\begin{array}{l}\text { Mean } \\
\pm \mathrm{SD}\end{array}$ \\
\hline $\begin{array}{l}\text { Interven } \\
\text { tion }\end{array}$ & $\begin{array}{c}97.61 \pm \\
3.29\end{array}$ & $63.68 \pm 2.74$ & 0.000 & $\begin{array}{l}33.92 \\
\pm 2.96\end{array}$ \\
\hline Control & $\begin{array}{c}65.12 \pm \\
3.67\end{array}$ & $71.03 \pm 4.59$ & 0.351 & $\begin{array}{c}5.96 \pm \\
3.41\end{array}$ \\
\hline$p$-value & 0.005 & 1.000 & & 0.000 \\
\hline
\end{tabular}

Similarly, Table 2 shows that the results of different group pairs test between groups before and after Dhikr Jaher denoted $\mathrm{p}$ value $=0.000(\mathrm{p}$ $<0,05)$ meaning that there is a significant difference of cortisol hormone level before and after Dhikr Jaher. The result of different test of paired group between first and second observation in control group indicated $\mathrm{p}=$ $0.0,351(\mathrm{p}>0,05)$ meaning there is no difference of cortisol hormone level between first and second observation. While the result of a different test in the unpaired group between group before treatment of Dhikr Jaher and control group obtained $\mathrm{p}$-value $=0.005(\mathrm{p}$ $<0.05$ ), meaning there is a significant difference of hormone cortisol level before Dhikr Jaher and first observation in control group. The different test result in the unpaired group between group after treatment of Dhikr Jaher and control group obtained $p$-value $=1.000(p>0.05)$, meaning that there was no significant difference of cortisol hormone level after Dhikr Jaher and second observation in control group. And the result of difference test of the unpaired panel in the treatment group of Dhikr Jaher and control group obtained $\mathrm{p}$-value $=0.000(\mathrm{p}<0.05)$, meaning there is a significant difference of cortisol hormone level between treatment group of Dhikr Jaher and control group.

Table 3 shows that the results of different group pairs test between groups before and after Dhikr Jaher obtained $\mathrm{p}$-value $=0.003 \quad(\mathrm{p}<0.05)$ meaning there is a significant difference in blood sugar levels before and after Dhikr Jaher. The result of different test of paired group between first and second observation in control group got $\mathrm{p}$-value $=0.470(\mathrm{p}>0,05)$ meaning there is no difference of blood glucose level between first and second observation. While the result of the different test in the unpaired group between group before treatment of Dzikir Jaher 
and control group got $p$-value $=0.369(p>0.05)$, meaning there is no significant difference of blood sugar level before Dhikr Jaher and first observation in control group. Different test results in the unpaired group between group after treatment of Dzikir Jaher and control group got $p=0,1912(p>0,05)$, meaning that there was no significant difference in blood sugar level after Dhikr Jaher and second observation in control group. The result of in the treatment group of Dzikir Jaher and control group was obtained $p=0.000(p<0.05)$, meaning that there was a significant difference of blood sugar level between the treatment group of Dhikr Jaher and the control group.

Table3. Differences in Blood Sugar Levels in Intervention Groups and Control Groups in the Elderly with Hypertension

\begin{tabular}{|l|c|c|c|l|}
\hline Groups & $\begin{array}{c}\text { Blood } \\
\text { Sugar } \\
\text { Level } \\
\text { (Pre) }\end{array}$ & $\begin{array}{c}\text { Blood } \\
\text { Sugar } \\
\text { Level } \\
\text { (Post) }\end{array}$ & palue & $\begin{array}{l}\text { Differe } \\
\text { nces }\end{array}$ \\
\hline & $\begin{array}{c}\text { Mean } \pm \\
\text { SD }\end{array}$ & $\begin{array}{c}\text { Mean } \pm \\
\text { SD }\end{array}$ & & $\begin{array}{l}\text { Mean } \pm \\
\text { SD }\end{array}$ \\
\hline Interven & $105.55 \pm$ & $101.25 \pm$ & $\mathbf{0 . 0 0 3}$ & $9.50 \pm$ \\
tion & 14.54 & 11.04 & & 1.04 \\
\hline Control & $101.25 \pm$ & $113.90 \pm$ & $\mathbf{0 . 4 7 0}$ & $0.20 \pm$ \\
& 11.04 & 23.18 & & 2.65 \\
\hline p-value & $\mathbf{0 . 3 6 9}$ & $\mathbf{0 . 1 9 2}$ & & $\mathbf{0 . 0 0 0}$ \\
\hline
\end{tabular}

\subsection{Discussion}

Based on the hypothesis test above, it is concluded that Dhikr Jaher influence stress level in elderly with hypertension, so the assumption that there is an influence of Dhikr Jaher to reduce stress in elderly with hypertension is accepted.

The results of this study supported (Hawari, 2005) which states that religious activities (worship) the form of prayer will minimize the risk to suffer heart disease and blood vessels (hypertension). Another opinion submitted by Saleh (2010) stated that dhikr could dilate the diameter of blood vessel walls that shrink due to anxiety or stress.

According to one of the research, subjects said that by reciting istighfar, make the heart to be calm and relaxed. This result is supported by the opinion of Yurisaldi (2010) which states that the process of dhikr by uttering phrases containing jahr letters, such as tawhid and istighfar sentences, increases the disposal of $\mathrm{CO} 2$ in the lungs. Yurisaldi also explained that when a person performing dhikr, the brain blood vessel reduction occurs for a moment due to the chemical response. Blood supply (decreased levels of oxygen and glucose) to the brain tissue decreases. This situation is immediately responded by the brain with a vaporized reflex that massively enters oxygen through the lungs to the brain with dilated blood vessel diameter. As a result, the supply of oxygen and glucose to the brain tissue increased rapidly. This condition will revitalize all cellular and microscale elements impacting the strength and vitality of brain cells. Also, the supply of oxygen in large quantities, mitochondria as the respiratory center of the cell will return to active and work regularly.

Based on the results of stress measurements and blood pressure after dhikr jaher, it is concluded that the stress score in elderly with hypertension decreased. In people with high blood pressure, relaxation can reduce stress levels. Provision of jaher dhikr as additional therapy is also needed because of the reduction of psychological stress and increased coping of stress can mediate the decrease in blood pressure in hypertensive patients (Linden, 2001). The results of the analysis prove that the intervention with the approach of spiritual behavior, proved very meaningful can reduce stress levels in elderly patients with hypertension.

The result of the bivariate analysis showed that there was a significant difference of cortisol hormone level before and after given dhikr jaher. Decreased levels of cortisol hormone that occurred in this study because there is a positive role of action dhikr jaher to the elderly who have increased levels of the hormone cortisol during hypertension. A decrease in the hormone cortisol indicates objectively the occurrence of a drop in stress or anxiety, which means the old experience a serenity after being given a jaher dhikr. The results of this study are supported by Yurisaldi (2010) explaining that the process of dhikr by uttering sentences containing jahr letters, such as Tawhid and istighfar convictions, increases the disposal of $\mathrm{CO} 2$ in the lungs. Also with dhikr, someone will get peace in the heart that will decrease the cortisol hormone.

The results of this study prove that the elderly with hypertension have increased cortisol hormone, in other words, that old with hypertension experience stress/anxiety. Stress and anxiety that occur during hypertension are hazardous for the elderly. Stress and anxiety will cause stress hormones such as increased cortisol which will affect the blood vessels. The 
release of these stress hormones results in systemic vasoconstriction.

According to Fotini et al., (2009), Christiansen et al. (2007) neuroendocrine factors are very useful as stress biomarkers because the neuroendocrine system responds first to stress and coordinates some psychological responses to stress responses including cardiovascular and immune systems. Cortisol is one of the biomarkers of stress. Stressors have an impact on cortisol response and Adrenocorticotropic Hormone levels (ACTH). Cortisol is involved in the conversion of fat and protein deposits into carbohydrates. Also, Clow (2001) states that in anxiety and depression, cortisol secretion increases.

The results of this analysis indicate that dhikr jaher has a right role to decrease the hormone cortisol, in other words, that dhikr jaher can reduce the stress of the elderly with hypertension. The intervention of jaher dhikr is a remembrance of God in the form of oral utterances gives clearer sound to guide the gesture of the heart. A person who performs dhikr will gain peace of soul and heart. When the emotional tension decreases then the hormone cortisol will decrease. This opinion is supported by Clow (2001) explains that cortisol circulates in the body and plays a role in the coping mechanism.

The study found a significant difference in the provision of dhikr jaher to decrease blood sugar levels in the elderly with hypertension who experience stress. The effect of stress on blood sugar levels in patients with hypertension will be able to affect the blood viscosity that can also affect blood pressure. According to Price and Wilson, (2006), stress conditions will increase the excretion of catecholamine, glucagon, glucocorticoid, endorphin and growth hormone. Stress causes excess production of cortisol, which works against the effects of insulin and causes high blood glucose levels. If a person experiences severe stress generated in his body, the resulting cortisol will increase and can reduce the body's sensitivity to insulin. Cortisol is an inhibitor of the function of insulin that makes glucose harder to enter the cells and increase blood glucose.

Stress can increase blood glucose content because stress stimulates endocrine organs to release epinephrine, which is a powerful effect in causing the onset of glyconeogenesis in the liver by releasing large amounts of glucose into the blood within minutes. This condition causes increased blood glucose levels during stress or tension.

\section{CONCLUSiON}

The results of this study indicate that dhikr jaher has a right role in decreasing stress levels, cortisol hormone and blood sugar levels, in other words that dhikr jaher can reduce stress in elderly with hypertension. This finding suggests that the role of dhikr jaher significantly contributes to decreased levels of cortisol hormone and blood sugar levels impacting on blood pressure.

\section{REFERENCES}

[1] Church, D. 2009. The Effect Of EFT (Emotional Freedom Techniques) On Athletic Performance: A Randomized Controlled Blind Trial. The Open Sports Sciences Journal, 2, 9499

[2] Clow A. 2001.The Physiology of Stress. In Jones F and Bright J Stress: Myth, Theory, and Research. Boston. Jones \& Bartlett Pub; 47-61

[3] Christiansen JJ, Djurhuus CB, Gravholt CH, Iversen P, Christiansen JS, Schmitz O, et al. 2007. Effects of cortisol on carbohydrate, lipid, and protein metabolism: studies of acute cortisol withdrawal in adrenocortical failure. $J$ Clin Endocrinol Metab.;3553-9

[4] Depkes RI.. 2007.Bulletin Jendela Data dan Informasi Kesehatan: Gambaran Kesehatan Lanjut Usia Di Indonesia. Jakarta (online) (HTTP://

www.depkes.go.id/download/Buletin\%20lanjut usia.pdf,

[5] Dinkes Propinsi Jawa Tengah. 2015. Profil Kesehatan Jawa Tengah

[6] Fotini, B, Irini L, John A, Ioannis M. Zervasc, Paraskevi P, Aggeliki A. Leonardouc, Georgios P, Dimitrios H, Konstantinos P, Chryssoula N. 2009. CSF and plasma cytokines at delivery and postpartum mood disturbances. Journal of Affective Disorders 115.; 287-292.

[7] Hawari, D. 2005. Al Qur'an : Ilmu kedokteran jiwa dan kesehatan jiwa. Yogyakarta : PT. Dana Bhakti Prima Yasa

[8] Linden, W., Lenz, J.W., \& Con, A. H. 2001. Individualized stress management for primary hypertension. Arch intern Med.

[9] Pinson, R. 2009. Ancaman "The Silent Killer" www.artikelindonesia.com

[10] Price, A. S., Wilson M. L., 2006. Patofisiologi Konsep Klinis Proses-Proses Penyakit. Alih Bahasa: dr. Brahm U. Penerbit. Jakarta: EGC

[11] Saleh, A. Y. 2010. Berdzikir untuk kesehatan syaraf. Jakarta: Penerbit Zaman 
[12] Wolf, J.R. 2006. Medical-Surgical Nursing: Clinical Managment for positive outcome. 7th ed.Philadephia: Elsivier Inc
[13] Yurisaldi. 2010. Berdzikir untuk kesehatan saraf. Jakarta: Zaman

Citation: Supriyadi, Ramelan Sugijana, Shobirun, Sudiarto, Sri Utami Dwiningsih, Religious Therapy as an Alternative Treatment in Reducing the Cortisol Hormone and Blood Sugar. ARC Journal of Public Health and Community Medicine. 2017; 2(3):1-6 doi:dx.doi.org/10.20431/2456-0596.0203001

Copyright: (C) 2017 Authors. This is an open-access article distributed under the terms of the Creative Commons Attribution License, which permits unrestricted use, distribution, and reproduction in any medium, provided the original author and source are credited. 